\title{
Bronchiolitis clinics and medical treatment
}

\author{
Fabio MIDULLA *, Laura PETRARCA, Antonella FRASSANITO,

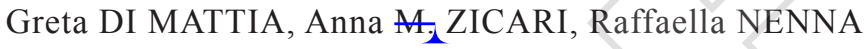

Department of Pediatrics, Sapienza University, Rome, Italy

*Corresponding author: Fabio Midulla, Department of Pediatrics, Sapienza University, Viale Regina Elena 324, 00161 Rome, Italy. E-mail:midulla@uniroma1.it

\section{ABSTRACT}

Bronchiolitis is the most common acute lower respiratory tract infection in infants and the first cause of hospitalization in this age group. Despite it has been studied for over 70 years, its management remains controversial and nowadays the treatment is only supportive. Pediatricians should be well acquainted with the clinical course of the disease. In particular, they should know that the severity of respiratory symptoms peaks between days 3-7 of the disease and dehydration is a key sign to consider for the management. In this review, we will discuss the most controversial points in the management of bronchiolitis according to six evidence-based guidelines, six clinical practice guidelines and five consensus-based reviews.

(Cite this article as: Midulla F, Petrarca L, Frassanito A, Di Mattia G, Zicari AM, Nenna R. Bronchiolitis clinics and medical treatment. Minerva Pediatr 2018;70:000-000. DOI: 10.23736/S0026-4946.18.05334-3)

KEY WORDS: Bronchiolitis - Guideline - Therapeutics - Disease management.

A cute bronchiolitis is the most common cause of hospitalization in infants. ${ }^{1-3}$ It is a viral lower respiratory infection and every year it is estimated that about 100,000 children are hospitalized due to bronchiolitis in the USA with a high social and economic burden. ${ }^{4-6}$

In this review, we will discuss the most controversial points in the management of bronchiolitis according to six evidence-based guidelines (EBG), ${ }^{7-12} 6$ clinical practice guidelines $(\mathrm{CPG})^{13-18}$ and 5 consensus-based reviews (CBR). ${ }^{19-23}$ Although guidelines have addressed bronchiolitis treatment worldwide, several knowledge gaps and controversies still exist. is it clear how acute viral bronchiolitis should be most appropriately defined, which diagnostic examinations are needed in managing these patients, when the child with bronchiolitis should be admitted, which is the most appropriate treatment and when infants can be safely discharged.

\section{Definition}

Despite ample evidence that bronchiolitis represents a continuum, including different diseases that may have in common similar phenotypes, brohehiolitis remains a diagnosis based on clinical signs and symptoms. ${ }^{24,25}$ Nobody has yet tried to define bronchiolitis according to clinical, pathological or biological heterogeneity.

The main differences in the clinical definition of bronchiolitis are age at presentation, and lung auscultatory findings. Most definitions have considered the age limit of 12 and 24 months, ${ }^{10,17}$ but others recommended 6 months ${ }^{26}$ or even more than 24 months. ${ }^{27,} 28$ The immune response, the lung anatomy and physiology differ with age, and these differences may influence the different phenotypic appearances of bronchiolitis. In older children, bronchiolitis can be confused with an episode of viral-induced wheezing bronchitis. ${ }^{29-31}$ 
Another important controversy about definition of bronchiolitis concerns the characteristic lung sounds observed during chest auscultation: predominant wheeze, or predominant presence of bilateral crackles. Wheezing is a high-pitched, musical, adventitious lung sound produced by turbulent airflow that passes through narrowed airways, and it reflects a bronchial disease such asthma. Conversely, crackles are caused by small airways popping open and alveoli collapsed by fluid, thus possibly reflecting two different entities affecting two different lung structures. ${ }^{32,33}$ No evidence yet shows whether bronchodilator responses depend from the infant's auscultatory sounds and/or age.

Specific studies in infants with a homogeneous definition of bronchiolitis should evaluate whether responses to medical treatment and long-lasting respiratory sequelae differ after the disease.

\section{VRS and bronchiolitis}

Bronchiolitis is a viral lower respiratory infection. Respiratory syncytial virus (VRS) is the most frequently detected virus in infants with bronchiolitis and it represents the major etiological agent in this disease. Over 10 consecutive epidemic seasons of bronchiolitis, enrolling 723 previously healthy term hospitalized infants, a virus was detected from nasopharyngeal aspirates in 351 infants and RSV was found in 234 (32.4\%), human Rhinovirus in 44 (6.1\%), human Bocavirus in $11(1.5 \%)$, human Metapneumovirus in $12(1.6 \%) .{ }^{34} \mathrm{RSV}$ has been recognized to cause a more severe form of bronchiolitis and to affect more frequently younger infants, ${ }^{35}$ while Rhinovirus, the second more frequent virus in this disease, usually affects older infants with a higher predisposition to atopy. ${ }^{36}$ Co-infections can also been found in about $10 \%$ of infants hospitalized with bronchiolitis, but it seems not to affect the clinical severity. ${ }^{37}$ Etiologic diagnosis is particularly useful for cohorting patients and for infection control in both hospitalized patients and outpatients and it has a role in research. There are not convincing data suggesting the virology testing to be routinely done in all patients presenting at the ED as it seems not to impact the management decisions. ${ }^{38}$

\section{Clinical evaluation}

The clinical course includes an incubation period of about 5 days followed by the onset of coryza that usually lasts 3 days. Although infants can present fever the very first days of runny nose, they are usually feverless when symptoms of an acute lower respiratory infection appear. As presenting symptom, apnea is always considered a risk factor for severe bronchiolitis. ${ }^{39,} 40$ In evaluating an infant with bronchiolitis, it is important to know that the risk of reduction in food intake with possible dehydration and of severe respiratory symptoms usually peaks between 3 to 7 days after the onset of rhinitis and cough. ${ }^{2}$ Equally important, during these days the child's clinical status can undergo a sudden worsening probably secondary to mucus plugs that may occlude respiratory and terminal bronchioles.

High fever during respiratory distress period is rare and is reported in only $30 \%$ of the patients. ${ }^{2}$ In the presence of high the child should be carefully evaluated to rule out other causes of fever. Several studies have reported that a proven secondary bacterial infection is present in only $1.2 \%$ of the infants with bronchiolitis, ${ }^{41,}, 42$ and should be suspected if the child presents a new fever and the clinical status worsens. A urine tract infection is reported in $1-7 \%$ of the febrile infants with bronchiolitis. ${ }^{43}$ Particular attention should be paid to infants younger than 30 days of age with high fever $\left(>39^{\circ} \mathrm{C}\right)$ and localized fine crackles at lung auscultation may indicate a possible bacterial pneumonia.

A key point to evaluate when considering a child with bronchiolitis is the food intake. In fact it is well known that it is the first clinical sign predicting the worsening of respiratory effort and it is a good marker of hypoxia. ${ }^{4}$

\section{Diagnostic examinations}

There is no agreement in literature on which are the most appropriate diagnostic examinations of bronchiolitis. The results of six EBG, six CPG, and five CBR (Table I, II, III) on the management of bronchiolitis show how opinions have remained unchanged or have developed over the past 20 years. All the guidelines and reviews 
TABLE I._Diagnostic tests in infants for bronchiolitis according to the six evidence-based guidelines.

\begin{tabular}{|c|c|c|c|c|c|c|}
\hline Parameters & $\begin{array}{l}\text { Scotland } \\
2006^{7}\end{array}$ & $\begin{array}{l}\text { Hong Kong } \\
2006^{8}\end{array}$ & $\begin{array}{l}\text { Mexico } \\
2015^{9}\end{array}$ & $\begin{array}{l}\text { NICE } \\
2015^{10}\end{array}$ & $\begin{array}{l}\text { Finland } \\
2015^{11}\end{array}$ & $\begin{array}{l}\text { Australasia } \\
2016^{12}\end{array}$ \\
\hline \multicolumn{7}{|l|}{ Oxygen saturation } \\
\hline Pulse oximetry at admission & Yes & Yes & - & Yes & - & Yes \\
\hline $\mathrm{SaO}_{2} \mathrm{a} / \mathrm{a}$ cut off for admission & $\leq 92 \%$ & - & $<90 \%$ & - & - & $<92 \%$ \\
\hline $\mathrm{SaO}_{2} \mathrm{a} / \mathrm{a}$ cut off for discharge & $>94 \%$ & - & $>94 \%$ & $>92 \%$ & - & $>92 \%$ \\
\hline Blood gas assessment only in severe forms & Yes & Yes & - & - & - & - \\
\hline \multicolumn{7}{|l|}{ Chest X-ray } \\
\hline Recommended as a routine & No & No & No & & - & No \\
\hline \multicolumn{7}{|l|}{ Blood tests } \\
\hline Recommended as a routine & No & No & $\mathrm{N}$ & & - & No \\
\hline \multicolumn{7}{|l|}{ Viral tests } \\
\hline Recommended as a routine & No & - & & & - & - \\
\hline For cohorting & Yes & - & $\mathrm{Ye}$ & & - & - \\
\hline \multicolumn{7}{|l|}{ Clinical variables } \\
\hline Presence of fever & Yes & & Ye & Yes & - & \\
\hline Severe respiratory symptoms peak & 72 hours & & & 3-5 days & & \\
\hline \multicolumn{7}{|l|}{ Microbiological tests } \\
\hline Recommended as a routine & No & & Yes & Yes & & No \\
\hline Urine culture & No & & & . & & No \\
\hline
\end{tabular}

TABLE II.-Diagnostic tests for infants with bronchiolitis according to the six clinical practice guidelines.

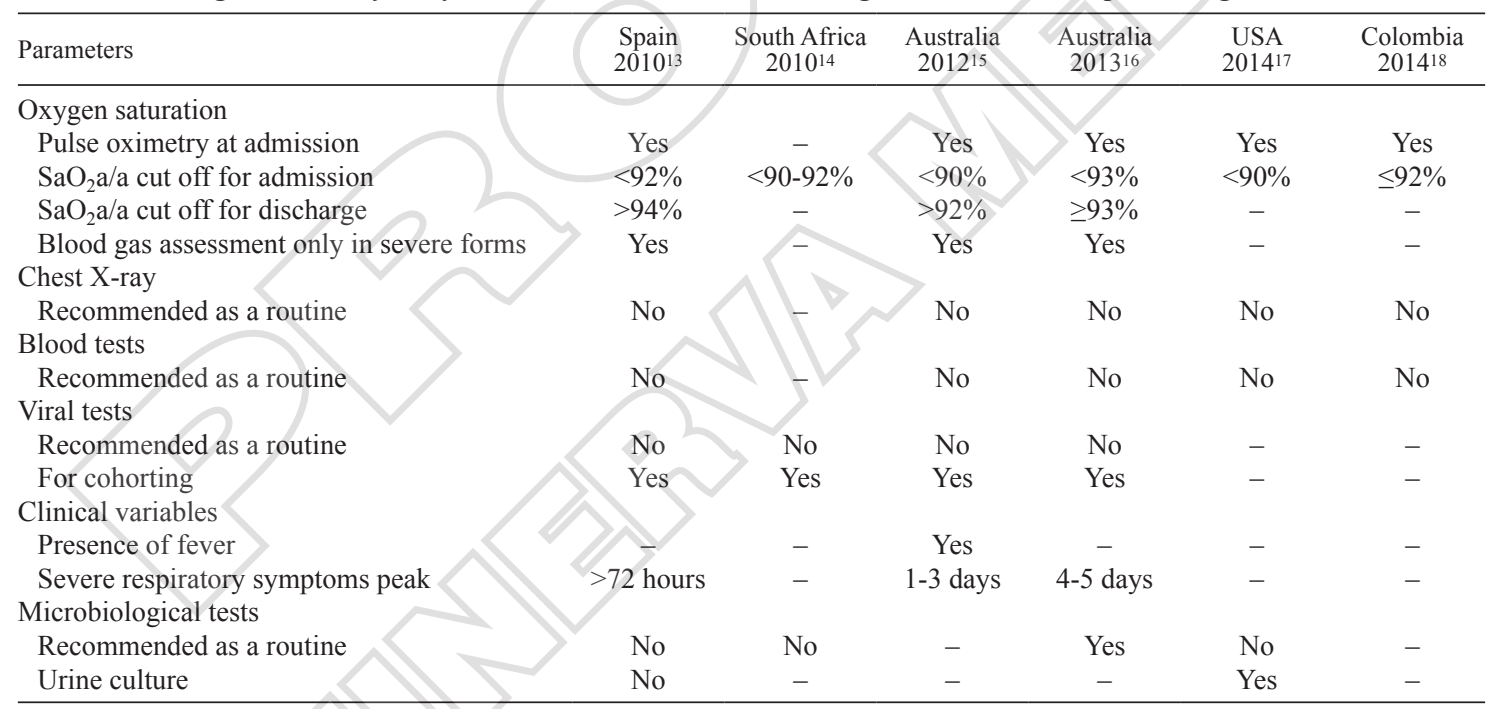

agree that all infants who come to the emergency room for bronchiolitis should have oxygen saturation $\left(\mathrm{SaO}_{2}\right)$ measured. $\mathrm{SaO}_{2}$ should be considered in combination with other clinical signs and it should be measured after the infant stabilization and upper airways gentle cleaning. ${ }^{45,46}$

Two EBG, 3 CPG and 1 CBR agree that arterial gas monitoring should be limited to infants with severe respiratory distress and those needing intensive care unit admission (Table I, II, III).
Regarding the role of laboratory findings in infants with bronchiolitis, all the guidelines and reviews agree that blood tests such as white-bloodcell counts and $\mathrm{C}$ reactive protein do not need to be measured routinely, whereas 2 clinical practice guidelines recommended that electrolytes should be measured only in children with severe dehydration needing intravenous (IV) fluid replacement (Table I, II, III).

Chest X-ray is not recommended in infants 
TABLE III.-Diagnostic tests for infants with bronchiolitis according to the five consensus-based

\begin{tabular}{|c|c|c|c|c|c|}
\hline Parameters & $\begin{array}{c}\text { Switzerland } \\
2003^{19}\end{array}$ & $\begin{array}{c}\text { Brazil } \\
2011^{20} \\
\end{array}$ & $\begin{array}{c}\text { Italy } \\
2014^{21}\end{array}$ & $\begin{array}{l}\text { Canada } \\
2014^{22}\end{array}$ & $\begin{array}{c}\text { Argentina } \\
2015^{23}\end{array}$ \\
\hline \multicolumn{6}{|l|}{ Oxygen saturation } \\
\hline Pulse oximetry at admission & Yes & Yes & Yes & Yes & Yes \\
\hline $\mathrm{SaO}_{2} \mathrm{a} / \mathrm{a}$ cut off for admission & $<92 \%$ & $<92 \%$ & $<90-92 \%$ & $<90 \%$ & $<94 \%$ \\
\hline $\mathrm{SaO}_{2} \mathrm{a} / \mathrm{a}$ cut off for discharge & $>92 \%$ & $>94 \%$ & $>93 \%$ & $>90 \%$ & $>94 \%$ \\
\hline Blood gas assessment only in severe forms & - & - & - & - & Yes \\
\hline \multicolumn{6}{|l|}{ Chest X-ray } \\
\hline Recommended as a routine & No & No & & No & No \\
\hline \multicolumn{6}{|l|}{ Blood tests } \\
\hline Recommended as a routine & No & No & & No & No \\
\hline \multicolumn{6}{|l|}{ Viral tests } \\
\hline Recommended as a routine & No & No & & No & No \\
\hline For cohorting & Yes & Yes & $\mathrm{Ye}$ & Yes & Yes \\
\hline \multicolumn{6}{|l|}{ Clinical variables } \\
\hline Presence of fever & - & & & - & \\
\hline Severe respiratory symptoms peak & - & 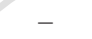 & & $>4 \mathrm{da}$ & $6 \mathrm{da}$ \\
\hline \multicolumn{6}{|l|}{ Microbiological tests } \\
\hline Recommended as a routine & No & No & - & No & . \\
\hline Urine culture & - & & - & Yes & - \\
\hline
\end{tabular}

with mild or moderate bronchiolitis and should be performed only in infants with severe bronchiolitis, or in those suspected of having a complication or bacterial pneumonia (Table I, I, III).

Bronchiolitis is viral disease and viral testing can be important to reduce the inappropriate use of antibiotics. Most of the guidelines and reviews recommend viral testing but only for clustering patients to reduce infection spreading in the department (Table I, II, III).

\section{Admission to the hospital}

Physicians sometimes find it difficult to decide when an infant with bronchiolitis should be admitted to the hospital. In making this decision, they should consider the presence of one or more risk factors for more severe disease, disease timing, the infants' clinical signs and symptoms, and family reliability.

Current guidelines reach a good consensus that infants without risk factors but with severe retractions, nasal flaring, $\mathrm{SaO}_{2}<90 \%$, respiratory rate $>70$ breaths/minute, apnea episodes and $<75 \%$ food intake should be hospitalized for monitoring and treatment.

Several risks factors exist for a severe course of bronchiolitis and infants with one of these risk factors should be carefully considered for hospital admission even in the absence of severe respi- ratory symptoms. An important risk factor is the infant's age. ${ }^{47}$ Many studies have reported that bronchiolitis is more severe in infants younger than 3 months of age. This age-related difference probably reflects the smaller bronchial tree and the immunological system immaturity in younger infants. Comorbidities such as severe prematurity, immunodeficiency, neurological diseases, chronic lung diseases, and congenital heart diseases are all associated with severe bronchiolitis. Finally, in deciding hospital admission, independently from the clinical severity, important features to consider are the parents' ability to manage the child at home and to recognize the signs of disease worsening. Passive smoke and low social economic status has been associated with an increased risk to develop bronchiolitis. ${ }^{48-51}$ The only protective factor for bronchiolitis is breastfeeding, a practice that should always be encouraged. ${ }^{51}$

Bronchiolitis is an evolving disease, and the clinical signs usually worsen between 3 and 7 days after the onset of coryza. Therefore infants, particularly if younger than 3 months of age, even if in general conditions, should be carefully monitored during disease progression because bronchiolitis can worsen.

Many clinical severity scores for bronchiolitis, based on feeding capacity, $\mathrm{SaO}_{2}$, retractions, nasal flaring, tachypnea and infant behavior have 
been published and should be used in evaluating the disease's severity and infant management. ${ }^{36,52,53}$

\section{Management}

\section{Supportive management}

Nowadays the treatment of bronchiolitis is mainly supportive. Bronchiolitis infant should undergo minimum handling and should be kept in the supine position at $45^{\circ}$ degrees and with the head slightly hyperextended.54 Intravenous or via nasogastric tube hydration should be provided when the child is not able to feed, and/or he/she manifests severe tachypnea (respiratory rate higher than 70 beats/minute). .55
A pivotal point in managing the child with bronchiolitis is oxygen administration. Most guidelines recommend oxygen when $\mathrm{SaO}_{2}$ is either lower than $92 \%$ or lower than $90 \%$ (Table IV, V, VI). Given that hemoglobin affinity for oxygen describes a sigmoid shape, a little difference in the blood oxygen partial tension occurs between $\mathrm{SaO}_{2}$ of $98 \%$ or $90 \%$. For this reason, oxygen can be administered safely even using the $90 \%$ threshold.

\section{Pharmacological management}

Although bronchiolitis has a well-known pathogenesis, no effective medical treatment is yet available for this disease. The various medications used so far have allowed scarce clinical

TABLE IV.- Support therapy in infants with bronchiolitis according to the six evidence-based guidelines.

\begin{tabular}{|c|c|c|c|c|c|c|}
\hline Parameters & $\begin{array}{l}\text { Scotland } \\
2006^{7}\end{array}$ & $\begin{array}{c}\text { Hong Kong } \\
2006^{8}\end{array}$ & $\begin{array}{c}\text { Mexico } \\
2015^{9} \\
\end{array}$ & $\begin{array}{l}\text { NICE } \\
2015^{10} \\
\end{array}$ & $\begin{array}{l}\text { Finland } \\
2015^{11}\end{array}$ & $\begin{array}{c}\text { Australasia } \\
2016^{12}\end{array}$ \\
\hline Physio-kinesiotherapy & & No & & & - & No \\
\hline \multicolumn{7}{|l|}{ Nasal suction } \\
\hline Recommended as a ro & & No & & & - & No \\
\hline Gently & & & & & - & Yes \\
\hline Frequently & & & & - & - & - \\
\hline \multicolumn{7}{|l|}{ Fluid maintenance } \\
\hline Nasogastric & Yes & & & Yes & - & Yes \\
\hline Intravenous & & & & Only in & - & Yes \\
\hline Nasogastric equivalen & & & - & - & - & Yes \\
\hline \multicolumn{7}{|l|}{ Oxygen administration } \\
\hline When to start & & & $<90 \%$ & $<92 \%$ & - & $<92 \%$ \\
\hline When to suspend & & . & $>94 \%$ & $>92 \%$ & - & $>92 \%$ \\
\hline
\end{tabular}

PICU: pediatric intensive care unit.

TABLE V.- Support therapy in infants with bronchiolitis according to the six clinical practice guidelines.

\begin{tabular}{|c|c|c|c|c|c|c|}
\hline Parameters & $\begin{array}{l}\text { Spain } \\
2010^{13}\end{array}$ & $\begin{array}{c}\text { South Africa } \\
2010^{14}\end{array}$ & $\begin{array}{c}\text { Australia } \\
2012^{15}\end{array}$ & $\begin{array}{c}\text { Australia } \\
2013^{16}\end{array}$ & $\begin{array}{c}\text { USA } \\
2014{ }^{17}\end{array}$ & $\begin{array}{c}\text { Colombia } \\
2014^{18}\end{array}$ \\
\hline Physio-kinesiotherap & No & No & No & No & No & - \\
\hline \multicolumn{7}{|l|}{ Nasal suction } \\
\hline Recommended as a & Yes & - & No & No & - & - \\
\hline Gently & - & - & Yes & - & - & - \\
\hline Frequently & - & - & Yes & - & - & - \\
\hline \multicolumn{7}{|l|}{ Fluid maintenance } \\
\hline Nasogastric & Yes & - & Yes & Yes & Yes & - \\
\hline Intravenous & $\begin{array}{l}\text { Only in } \\
\text { PICU }\end{array}$ & - & $\begin{array}{c}\text { Only in } \\
\text { PICU }\end{array}$ & $\begin{array}{c}\text { Only in } \\
\text { PICU }\end{array}$ & Yes & - \\
\hline Nasogastric equivalent to intravenous & - & - & Yes & - & Yes & - \\
\hline \multicolumn{7}{|l|}{ Oxygen administration } \\
\hline When to start & $<90-92 \%$ & $<90-92 \%$ & $<95 \%$ & $<93 \%$ & $<90 \%$ & $\leq 92 \%$ \\
\hline When to suspend & $>94 \%$ & - & $>95 \%$ & $\geq 93 \%$ & - & - \\
\hline
\end{tabular}

PICU: pediatric intensive care unit. 
TABLE VI.-Support therapy in infants with bronchiolitis according to the five consensus-based

\begin{tabular}{|c|c|c|c|c|c|}
\hline Parameters & $\begin{array}{l}\text { Switzerland } \\
2003^{19}\end{array}$ & $\begin{array}{l}\text { Brazil } \\
2011^{20}\end{array}$ & $\begin{array}{l}\text { Italy } \\
2014^{21}\end{array}$ & $\begin{array}{l}\text { Canada } \\
2014^{22}\end{array}$ & $\underset{2015^{23}}{\text { Argentina }}$ \\
\hline Physio-kinesiotherapy & No & No & No & No & No \\
\hline \multicolumn{6}{|l|}{ Nasal suction } \\
\hline Recommended as a routine & Yes & Yes & Yes & Yes & - \\
\hline Gently & - & - & Yes & Yes & - \\
\hline Frequently & - & - & - & - & - \\
\hline \multicolumn{6}{|l|}{ Fluid maintenance } \\
\hline Nasogastric & Yes & Yes & Yes & Yes & - \\
\hline Intravenous & - & Only in PICU & Yes & Yes & - \\
\hline Nasogastric equivalent to intravenous & - & - & & Yes & - \\
\hline \multicolumn{6}{|l|}{ Oxygen administration } \\
\hline When to start & $\leq 92 \%$ & $<92 \%$ & $90-92$ & $<90 \%$ & $<94 \%$ \\
\hline When to suspend & $>94 \%$ & $>94 \%$ & $>93 \%$ & $>90 \%$ & $>94 \%$ \\
\hline
\end{tabular}

improvement and controversial results. Despite evidence reported by many guidelines published on bronchiolitis management, some therapeutic agents are still used worldwide in the treatment of infants hospitalized for this disease. ${ }^{66}$ Specific studies in infants with a restrictive definition of bronchiolitis should evaluate responses to medical treatment.

\section{Bronchodilators}

Bronchodilators used for managing infants with bronchiolitis include albuterol (beta-adrenergic agent), ipratropium bromide (anticholinergic agent) and epinephrine (adrenergic agent). A Cochrane review on albuterol reporting the results of 22 clinical trials enrolling 1428 infants with bronchiolitis, showed no significant improvement in clinical score, in $\mathrm{SaO}_{2}$, in the rate of hospital admission, and in the length of hospitalization among infants treated with albuterol compared to those receiving placebo. ${ }^{57}$ The results of these clinical trials should be also considered with caution because the controversial results observed in some patients reflect the various clinical definitions. A positive effect has possibly been shown in older patients possibly having recurrent wheezing episodes. All the guidelines analyzed reported that albuterol should not be used routinely in infants with bronchiolitis (Table VII, VIII, IX). Twelve guidelines reported that albuterol should be tried only in older infants with predominant wheezing at auscultation and

TABLE VII.- - Therapy in infants with bronchiolitis according to the six evidence-based guidelines.

\begin{tabular}{|c|c|c|c|c|c|c|}
\hline Parameters & $\begin{array}{l}\text { Scotland } \\
2006^{7}\end{array}$ & $\begin{array}{c}\text { Hong Kong } \\
2006^{8}\end{array}$ & $\begin{array}{c}\text { Mexico } \\
2015^{9}\end{array}$ & $\begin{array}{c}\text { NICE } \\
2015^{10}\end{array}$ & $\begin{array}{l}\text { Finland } \\
2015^{11}\end{array}$ & $\begin{array}{c}\text { Australasia } \\
2016^{12}\end{array}$ \\
\hline \multicolumn{7}{|l|}{ Antibiotics } \\
\hline Recommended as a & No & No & No & No & - & No \\
\hline Used in the PICU & - & Yes & - & - & - & - \\
\hline \multicolumn{7}{|l|}{$\beta_{2}$ agonists } \\
\hline Recommended as a & No & No & No & No & No & No \\
\hline Trial & - & Yes & Yes & - & - & No \\
\hline Anticholinergics & No & No & - & No & - & No \\
\hline \multicolumn{7}{|l|}{ Epinephrine } \\
\hline Recommended as a routine & No & No & No & No & No & No \\
\hline Recommended as a routine in outpatients & - & Yes & - & - & No & No \\
\hline \multicolumn{7}{|l|}{ Corticosteroids } \\
\hline Inhaled & No & No & No & No & No & No \\
\hline Oral & No & No & No & No & No & No \\
\hline Used in the PICU & - & Yes & - & - & No & - \\
\hline $3 \%$ hypertonic saline & - & - & Yes & No & Yes & No \\
\hline
\end{tabular}


TABLE VIII.-Therapy in infants with bronchiolitis according to the 6 clinical practice guidelines.

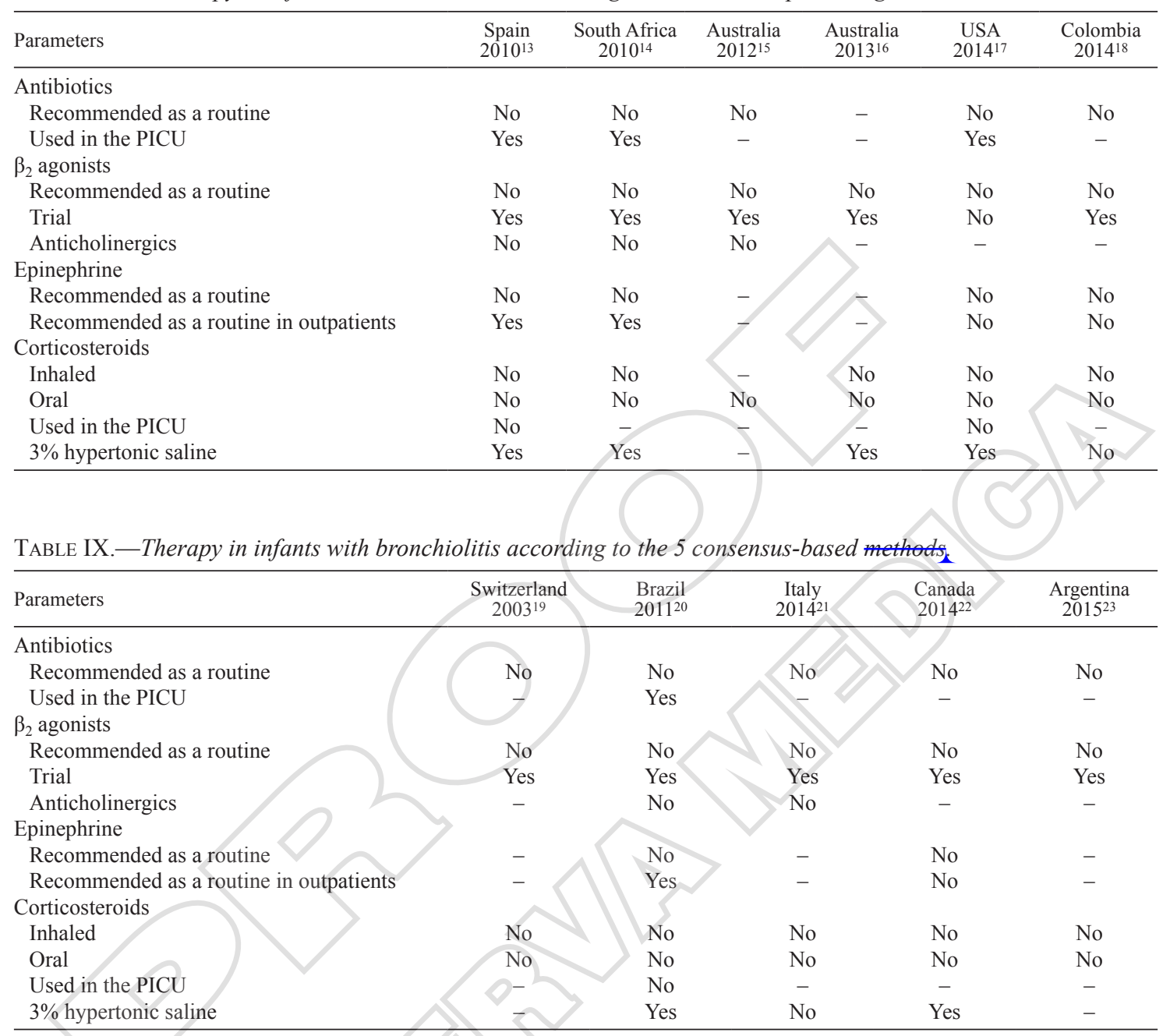

PICU: pediatric intensive care unit.

with risk factors for atopy. Future studies may be needed to analyze the effect of albuterol by grouping infants with acute viral bronchiolitis according to age and auscultatory findings.

A Cochrane review on ipratropium bromide, reporting results of six clinical trials involving 321 infants, concluded that more evidence is needed before we can consider the use of this nebulized anticholinergic agent in the treatment of infants with bronchiolitis. ${ }^{58}$ All the analyzed guidelines agree that nebulized ipratropium bromide should be avoided in infants with bronchiolitis.

Epinephrine is an adrenergic agent possessing both alpha and beta activities. Unlike albuterol, the drug might also act by reducing edema in the bronchial mucosa. A Cochrane review reported the results of 19 studies enrolling 2,256 infants younger than 2 years with acute viral bronchiolitis and comparing epinephrine with placebo. ${ }^{59}$ The study showed a reduction in the admission rate at day 1 but not at day 7 after an emergency department visits in those infants receiving epinephrine but found no differences in length of hospital stay for inpatients. When they analyzed studies comparing epinephrine versus albuterol they found no admission differences for outpatients, but inpatients receiving epinephrine had a shorter hospital stay than those receiving albuterol. 
A multicenter randomized double-blind trial conducted in 404 hospitalized infants with bronchiolitis has evaluated treatment with nebulized epinephrine at a fixed-schedule or on-demand versus placebo, using the length of hospital stay as primary outcome. No significant differences were observed in the length of hospital stay between the two groups (epinephrine vs placebo) when epinephrine was administered at a fixed time. Conversely, the hospital stay was 12 hours shorter in the group of infants who were treated with epinephrine on demand than in the infants receiving epinephrine at a fixed-schedule. ${ }^{60}$

All the guidelines recommend against using epinephrine routinely in inpatients. Only four guidelines recommend the use of epinephrine in outpatients in the emergency department with acute viral bronchiolitis (Table VII, VIII, IX).

\section{Corticosteroids}

Systemic or inhaled corticosteroids are ineffective in infants with bronchiolitis. A Cochrane review reported the results of 17 trials on 2596 participants. The study provided no support for systemic or inhaled corticosteroids in infants with bronchiolitis because they do not change the admission rate and length of hospital. ${ }^{61}$

None of the analyzed guidelines support the use of corticosteroids in the treatment of infants with bronchiolitis (Table VII, VIII, IX). Only one guideline suggests using them in infants hospitalized in the intensive care unit.

\section{Hypertonic saline}

A Cochrane review including seven studies on 581 infants has reported that $3 \%$ nebulized hypertonic reduces the length of hospital stay among infants hospitalized with mild-to-moderate bronchiolitis and improves the clinical severity score. ${ }^{62}$ Conversely, two recent multicenter randomized double-blind studies performed in Europe and in Australia reported different results. They showed that $3 \%$ hypertonic saline did not change the length of hospital stay and duration of oxygen administration in hospitalized infants with bronchiolitis. ${ }^{63,64}$

Recently, Zhang et al. published a Cochrane review including 28 trials involving 4195 infants with bronchiolitis. 2222/4195 infants received hypertonic saline $3 \%$ and showed significant shorter length of hospital stay (GRADE quality of evidence: low), lower post-inhalation clinical score (GRADE quality of evidence: low) and lower risk of hospitalization (GRADE quality of evidence: moderate) than infants treated with normal saline. ${ }^{62}$

Discordant recommendations come also from the guidelines. Only eight guidelines recommend the use of nebulized 3\% hypertonic saline in infants with bronchiolitis (Table VII, VIII, IX). Considering the last multicenter studies, we think that at the moment there is insufficient evidence to recommend the use of hypertonic saline in hospitalized infants with bronchiolitis.

\section{Antibiotics}

Despite it is well recognize that bronchiolitis is a viral infection, the difficulties of the differential diagnosis with a bacterial infection induce many physicians to use antibiotics for its management. A Cochrane review reporting results of five studies with 543 infants showed minimal evidence to support the use of antibiotics for bronchiolitis. ${ }^{65}$ Antibiotics should be used only in infants with severe respiratory symptoms who are at risk a secondary bacterial infection.

Macrolides have been tested in infants with bronchiolitis. A double-blind, placebo-controlled, randomized clinical trial with azithromycin in infants hospitalized for bronchiolitis demonstrated no difference in the length of hospital stay, duration of oxygen treatment and hospital readmission. ${ }^{66}$ Conversely, in a small randomized double-blind clinical trial performed in 21 infants with bronchiolitis, clarithromycin seemed able to reduce the length of hospital stay and the duration of oxygen administration. ${ }^{67}$ Yet the studies conducted so far on macrolides in infants with bronchiolitis cannot yet suggest the use of these antibiotics in infants with this disease.

All the guidelines agree on the fact that antibiotics should not be used routinely in infants with bronchiolitis unless they manifest signs of a secondary bacterial infection. Five guidelines recommend the use of antibiotics in the intensive care unit (Table VII, VIII, IX). 


\section{Other medications}

A multicenter randomized double-blind controlled clinical trial in 225 oxygen-dependent infants hospitalized for bronchiolitis has shown that nebulized human deoxyribonucleases (DNase) failed to reduce the length of hospital stay. ${ }^{68}$ Yet, nebulized DNase seems effective in infants with bronchiolitis complicated with a lobar collapse. ${ }^{69}$ This observation awaits confirmation from other studies.

A Cochrane review including 5 studies with 1296 infants hospitalized for bronchiolitis showed that montelukast has no effect on the length of hospital stay and the clinical severity score. 70

One study evaluated the effect of IV magnesium sulfate (MS) in infants with bronchiolitis. ${ }^{71}$ No difference was observed in the readiness for discharge and bronchiolitis severity score between infants receiving IV MS or placebo. ${ }^{71}$

None of the analyzed guidelines recommends the use of DNase, montelukast and IV MS in the treatment of infants with bronchiolitis.

\section{Hospital discharge}

Another important question relates to when an infant hospitalized with bronchiolitis can be safely discharged to home. ${ }^{72,73}$ In their prospective multiyear cohort study in 1,916 children admitted to the hospital for bronchiolitis, Mansbach et $a l$. , found that in $88 \%$ of the infants the median number of days for clinical improvement was 4 . The main risk factors for a longer hospital stay were: age $<2$ months, gestational age $<37$ weeks, severe retractions, inadequate oral intake and apnea. ${ }^{74}$ The most important clinical variables to be considered for discharging an infant with bronchiolitis are food intake, respiratory status and $\mathrm{SaO}_{2}$. In a prospective observational study performed in 68 infants hospitalized for bronchiolitis, Cunningham et al., have shown that the average time needed to resolve feeding difficulties was 22 hours. This time was shorter than the time needed to stabilize $\mathrm{SaO}_{2}>94 \%$. Food intake is therefore a highly sensitive criterion to take into consideration both when respiratory status worsens and when the child starts to recover from bronchiolitis. 75
Another important point that can influence the length of hospital stay is the decision to monitor $\mathrm{SaO}_{2}$ continuously or intermittently. When the child is hospitalized, continuous monitoring should be reserved to very severe hypoxemic cases, especially in the first 24 hours. Intermittent $\mathrm{SaO}_{2}$ measurement is recommended in all other circumstances, as it was demonstrated in a randomized study on the use of intermittent vs continuous pulse oximetry for non-hypoxemic infants hospitalized for bronchiolitis. ${ }^{76}$ All the guidelines analyzed agree that when $\mathrm{SaO}_{2}$ is between $92-94 \%$ the child can be safely discharged from the hospital.

In conclusion, a child with bronchiolitis can be safely discharged from the hospital when oral fluid intake becomes adequate $(>75 \%$ of the daily needs), the $\mathrm{SaO}_{2}$ is $>92 \%$ and the clinical conditions are stable.

\section{New therapeutics}

Over the last decade, researchers have developed experimentations on new therapeutics for viral bronchiolitis with a particular focus on antivirals and vaccines. There are only two antivirals that has been approved by the Food and Drug Administration for treatment of RSV infection: inhaled ribavirin that it is no longer recommended because of insufficient proof of effectiveness, and Palivizumab, a humanized monoclonal antibody that targets the RSV F protein, administered for immunoprophylaxis in high-risk infants. Recently, there are under investigation in clinical trials 11 new antivirals for RSV that belong to four main therapeutic classes: immunoglobulins, siRNA-interference, fusion inhibitors, and small molecules. ${ }^{77}$

Regarding the development of a RSV vaccine, the landscape has recently expanded. Up to now there are 19 vaccine candidates using four approaches: particle-based, live-attenuated or chimeric, subunit and vector-based. Those prophylactic measures are designed to protect the population of young infants and children that are at high risk of severe forms and the older adults, an emerging target of at risk subjects. ${ }^{78}$ 


\section{Conclusions}

Despite the many publications, bronchiolitis treatment does not significantly differ from what has been proposed almost 70 years ago. ${ }^{79}$ Pediatricians taking care of infants with bronchiolitis should be well acquainted with its clinical symptoms and course.

\section{References}

1. Meissner HC. Viral bronchiolitis in children. N Engl J Med 2016;374:1793-4.

2. Florin TA, Plint AC, Zorc JJ. Viral bronchiolitis. Lancet 2017;389:211-24.

3. Øymar K, Skjerven HO, Mikalsen IB. Acute bronchiolitis in infants, a review. Scand J Trauma Resusc Emerg Med $2014 ; 22: 23$

4. Shi T, McAllister DA, O'Brien KL, Simoes EA, Madhi $\mathrm{SA}$, Gessner BD, et al.; RSV Global Epidemiology Network. Global, regional, and national disease burden estimates of acute lower respiratory infections due to respiratory syncytial virus in young children in 2015: a systematic review and modelling study. Lancet 2017;390:946-58.

5. Nair H, Nokes DJ, Gessner BD, Dherani M, Madhi SA, Singleton RJ, et al. Global burden of acute lower respiratory infections due to respiratory syncytial virus in young children: a systematic review and meta-analysis. Lancet 2010;375:1545-55.

6. Papoff P, Moretti C, Cangiano G, Bonci E, Roggini M, Pierangeli $\mathrm{A}$, et al. Incidence and predisposing factors for severe disease in previously healthy term infants experiencing their first episode of bronchiolitis. Acta Paediatr 2011;100:e17-23.

7. Scottish Intercollegiate Guidelines Network. Bronchiolitis in children; 2006 [Internet]. Available from: www.lothianrespiratorymcn.scot.nhs.uk/wp-content/uploads/2010/11/Sign91-Bronchiolitis-in-children.pdf [cited 2018, Oct 17].

8. Tam A, Lam SY, Li A, Ma K, Sit SC, Sung R, et al. Clinical Guidelines on the Management of Acute Bronchiolitis. HK J Paediatr 2006;11:235-41.

9. México, Gobierno de la República - Secretaría de Salud. Diagnóstico y tratamiento de bronquiolitis aguda en niñas/ niños y en el primer nivel de atención. Actualización 2015 [Internet]. Available from: www.cenetec.salud.gob.mx/descargas/gpc/CatalogoMaestro/032 GPC BronquiolitisPed/ IMSS_032_08_EyR.pdf [cited 2018, Oct 17].

10. NICE. (2015) Bronchiolitis: diagnosis and management of bronchiolitis in children, clinical guideline NG9. National Institute for Clinical Excellence (NICE).

11. Tapiainen T, Aittoniemi J, Immonen J, Jylkkä H, Meinander T, Nuolivirta $\mathrm{K}$, et al. Finnish guidelines for the treatment of laryngitis, wheezing bronchitis and bronchiolitis in children. Acta Paediatr 2016;105:44-9.

12. O'Brien S, Borland ML, Cotterell E, Armstrong D, Babl F, Bauert P, et al.; Paediatric Research in Emergency Departments International Collaborative (PREDICT) Network, Australasia. Australasian bronchiolitis guideline. J Paediatr Child Health 2018

13. Clinical Practice Guideline on Acute Bronchiolitis. Clinical practice guidelines in the Spanish national healthcare system; 2010 [Internet]. Available from: www.guiasalud.es/ GPC/GPC 475_Bronchiolitis_AIAQS_compl_en.pdf [cited 2018, Oct 17 ].

14. Green RJ, Zar HJ, Jeena PM, Madhi SA, Lewis H. South African guideline for the diagnosis, management and prevention of acute viral bronchiolitis in children. S Afr Med J 2010;100:320, 322-5.

15. Health NS. Infants and Children - Acute Management of Bronchiolitis; 2012 [Internet]. Available from: www1.health. nsw.gov.au/pds/ArchivePDSDocuments/PD2012_004.pdf [cited 2018, Oct 17].

16. SA Child Health Clinical Network. Management. South Australian paediatric practice guidelines; 2015 [Internet] Available from: www.sahealth.sa.gov.au/wps/wcm/connect/ 80c8b2004329b65c8219ee8bf287c74e/Seizures+in+Childre $\mathrm{n}+$ Clinical+Guideline+-+Dec2015.pdf?MOD=AJPERES\&C ACHEID=ROOTWORKSPACE-80c8b2004329b65c8219ee8bf287c74e-1YyvwUu [cited 2018, Oct 17].

17. Ralston SL, Lieberthal AS, Meissner HC, Alverson BK, Baley JE, Gadomski AM, et al.; American Academy of Pediatrics. Clinical practice guideline: the diagnosis, management, and prevention of bronchiolitis. Pediatrics 2014;134:e1474 502 .

18. Contreras Ortiz JO. Guía de práctica clínica para la evaluación del riesgo y manejo inicial de la neumonía en niños y niñas menores de 5 años y bronquiolitis en niños y niñas menores de 2 años. Sistema general de seguridad social en salud; 2014 [Internet]. Available from: www.iets.org.co/ reportes-iets/Documentacin\%20Reportes/GuiaparaUsuarios. pdf [cited 2018, Oct 17].

19. Barben J, Hammer J. Current management of acute bronchiolitis in Switzerland. Swiss Med Wkly 2003;133:9-15.

20. Kfouri RA, Rodrigues Sadeck LS. Diretrizes para o manejo da infeccão causada pelo vírus sincicial respiratòrio. Sociedade brasileira de pediatria; 2011 [Internet]. Available from: www.sbp.com.br/fileadmin/user upload/ Diretrizes manejo infeccao causada VSR2017.pdf [cited 2018, Oct 17].

21. Baraldi E, Lanari M, Manzoni P, Rossi GA, Vandini S, Rimini A, et al. Inter-society consensus document on treatment and prevention of bronchiolitis in newborns and infants. Ital J Pediatr 2014;40:65.

22. Friedman JN, Rieder MJ, Walton JM; Canadian Paediatric Society, Acute Care Committee, Drug Therapy and Hazardous Substances Committee. Bronchiolitis: recommendations for diagnosis, monitoring and management of children one to 24 months of age. Paediatr Child Health 2014;19:485-98.

23. Moreno L, Ferrero F. Recomendaciones para el manejo de las infecciones respiratorias agudas bajas en menores de 2 anos. Sociedad Argentina de Pediatrìa 2015.

24. Hancock DG, Charles-Britton B, Dixon DL, Forsyth KD The heterogeneity of viral bronchiolitis: A lack of universal consensus definitions. Pediatr Pulmonol 2017;52:1234-40.

25. Fernandes RM, Andrade MG, Constant C, Malveiro D, Magalhães M, Abreu D, et al. Acute viral bronchiolitis: physician perspectives on definition and clinically important outcomes. Pediatr Pulmonol 2016;51:724-32.

26. Nuolivirta $K$, He Q, Gröndahl-Yli-Hannuksela K, Koponen P, Korppi M, Helminen M. Mannose-binding lectin gene polymorphisms in infants with bronchiolitis and post-bronchiolitis wheezing. Allergol Int 2012;61:305-9.

27. Grześk E, Kołtan S, Dębski R, Wysocki M, Gruszka M, Kubicka M, et al. Concentrations of IL-15, IL-18, IFN- $\gamma$ and activity of CD4+, CD8+ and NK cells at admission in children with viral bronchiolitis. Exp Ther Med 2010;1:873-7. 
28. Uzuner N, Gurcu O, Olmez D, Babayigit A, Islekel H, Karaman O, et al. Relation between serum IL-4, IL-13 and IFN-gamma levels and recurrence of wheezing episodes in infants with acute bronchiolitis. Pediatr Allergy Immunol 2008;19:648-51.

29. Korppi M. Virus-induced wheezing in infants aged 1224 months and bronchiolitis in infants under 6 months are different clinical entities. Acta Paediatr 2015;104:e539.

30. Korppi M, Koponen P, Nuolivirta K. Upper age limit for bronchiolitis: 12 months or 6 months? Eur Respir J 2012;39:787-8, author reply 788-9.

31. Korppi M. Asthma after bronchiolitis: the outcome and risk factors depend on the age definition of bronchiolitis. Pediatr Pulmonol 2016;51:1274-5.

32. Melbye H, Garcia-Marcos L, Brand P, Everard M, Priftis K, Pasterkamp H. Wheezes, crackles and rhonchi: simplifying description of lung sounds increases the agreement on their classification: a study of 12 physicians' classification of lung sounds from video recordings. BMJ Open Respir Res 2016;3: 000136.

33. Pasterkamp H, Brand PL, Everard M, Garcia-Marcos L, Melbye H, Priftis KN. Towards the standardisation of lung sound nomenclature. Eur Respir J 2016;47:724-32.

34. Cangiano G, Nenna R, Frassanito A, Evangelisti M, Nicolai A, Scagnolari C, et al. Bronchiolitis: analysis of 10 consecutive epidemic seasons. Pediatr Pulmonol 2016;51: $1330-5$.

35. García CG, Bhore R, Soriano-Fallas A, Trost M, Chason $\mathrm{R}$, Ramilo $\mathrm{O}$, et al. Risk factors in children hospitalized with RSV bronchiolitis versus non-RSV bronchiolitis. Pediatrics 2010;126:e1453-60.

36. Midulla F, Scagnolari C, Bonci E, Pierangeli A, Antonelli $\mathrm{G}$, De Angelis D, et al. Respiratory syncytial virus, human bocavirus and rhinovirus bronchiolitis in infants. Arch Dis Child 2010;95:35-41.

37. Petrarca L, Nenna R, Frassanito A, Pierangeli A, Leonardi S, Scagnolari C, et al. Acute bronchiolitis: influence of viral co-infection in infants hospitalized over 12 consecutive epidemic seasons. J Med Virol 2018;90:631-8.

38. Stollar F, Alcoba G, Gervaix A, Argiroffo CB. Virologic testing in bronchiolitis: does it change management decisions and predict outcomes? Eur J Pediatr 2014;173:1429-35.

39. Schroeder AR, Mansbach JM, Stevenson M, Macias CG, Fisher ES, Barcega B, et al. Apnea in children hospitalized with bronchiolitis. Pediatrics 2013;132:e1194-201.

40. Willwerth BM, Harper MB, Greenes DS. Identifying hospitalized infants who have bronchiolitis and are at high risk for apnea. Ann Emerg Med 2006;48:441-7.

41. Librizzi J, McCulloh R, Koehn K, Alverson B. Appropriateness of testing for serious bacterial infection in children hospitalized with bronchiolitis. Hosp Pediatr 2014;4:33-8.

42. Ralston S, Hill V, Waters A. Occult serious bacterial infection in infants younger than 60 to 90 days with bronchiolitis: a systematic review. Arch Pediatr Adolesc Med 2011;165:951-6.

43. Levine DA, Platt SL, Dayan PS, Macias CG, Zorc JJ, Krief W, et al.; Multicenter RSV-SBI Study Group of the Pediatric Emergency Medicine Collaborative Research Committee of the American Academy of Pediatrics. Risk of serious bacterial infection in young febrile infants with respiratory syncytial virus infections. Pediatrics 2004; 113:1728-34.

44. Corrard F, de La Rocque F, Martin E, Wollner C, Elbez A, Koskas M, et al. Food intake during the previous $24 \mathrm{~h}$ as a percentage of usual intake: a marker of hypoxia in infants with bronchiolitis: an observational, prospective, multicenter study. BMC Pediatr 2013;13:6.

45. Schreiber S, Ronfani L, Ghirardo S, Minen F, Taddio A, Jaber $\mathrm{M}$, et al. Nasal irrigation with saline solution significantly improves oxygen saturation in infants with bronchiolitis. Acta Paediatr 2016;105:292-6.

46. Moschino L, Mario F, Carraro S, Visentin F, Zanconato $\mathrm{S}$, Baraldi E. Is nasal suctioning warranted before measuring O2 saturation in infants with bronchiolitis? Arch Dis Child 2016;101:114-5.

47. Hall CB, Weinberg GA, Blumkin AK, Edwards KM, Staat MA, Schultz AF, et al. Respiratory syncytial virus-associated hospitalizations among children less than 24 months of age. Pediatrics 2013;132:e341-8.

48. DiFranza JR, Masaquel A, Barrett AM, Colosia AD, Mahadevia PJ. Systematic literature review assessing tobacco smoke exposure as a risk factor for serious respiratory syncytial virus disease among infants and young children. BMC Pediatr 2012;12:81.

49. Bradley JP, Bacharier LB, Bonfiglio J, Schechtman KB, Strunk R, Storch G, et al. Severity of respiratory syncytial virus bronchiolitis is affected by cigarette smoke exposure and atopy. Pediatrics 2005;115:e7-14.

50. Nenna R, Cutrera R, Frassanito A, Alessandroni C, Nicolai A, Cangiano $\mathrm{G}$, et al. Modifiable risk factors associated with bronchiolitis. Ther Adv Respir Dis 2017;11:393-401.

51. Nicolai A, Frassanito A, Nenna R, Cangiano G, Petrarca $\mathrm{L}$, Papoff $\mathrm{P}$, et al. Risk factors for virus-induced acute respiratory tract infections in children younger than 3 years and recurrent wheezing at 36 months follow-up after discharge. Pediatr Infect Dis J 2017;36:179-83.

52. Fernandes RM, Plint AC, Terwee CB, Sampaio C, Klassen TP, Offringa M, et al. Validity of bronchiolitis outcome measures. Pediatrics 2015;135:e1399-408.

53. McCallum GB, Morris PS, Wilson CC, Versteegh LA, Ward LM, Chatfield MD, et al. Severity scoring systems: are they internally valid, reliable and predictive of oxygen use in children with acute bronchiolitis? Pediatr Pulmonol 2013;48:797-803.

54. Nagakumar P, Doull I. Current therapy for bronchiolitis Arch Dis Child 2012;97:827-30.

55. Kennedy N, Flanagan N. Is nasogastric fluid therapy a safe alternative to the intravenous route in infants with bronchiolitis? Arch Dis Child 2005;90:320-1.

56. Macias CG, Mansbach JM, Fisher ES, Riederer M, Piedra PA, Sullivan AF, et al. Variability in inpatient management of children hospitalized with bronchiolitis. Acad Pediatr 2015;15:69-76.

57. Gadomski AM, Scribani MB. Bronchodilators for bronchiolitis. Cochrane Database Syst Rev 2014;(6):CD001266.

58. Everard ML, Bara A, Kurian M, Elliott TM, Ducharme $\mathrm{F}$, Mayowe V. Anticholinergic drugs for wheeze in children under the age of two years. Cochrane Database Syst Rev 2005;(3):CD001279.

59. Hartling L, Bialy LM, Vandermeer B, Tjosvold L, Johnson DW, Plint AC, et al. Epinephrine for bronchiolitis. Cochrane Database Syst Rev 2011;(6):CD003123.

60. Skjerven HO, Hunderi JO, Brügmann-Pieper SK, Brun $\mathrm{AC}$, Engen H, Eskedal L, et al. Racemic adrenaline and inhalation strategies in acute bronchiolitis. $\mathrm{N}$ Engl J Med 2013;368:2286-93.

61. Fernandes RM, Bialy LM, Vandermeer B, Tjosvold L, Plint AC, Patel H, et al. Glucocorticoids for acute viral bronchiolitis in infants and young children. Cochrane Database Syst Rev 2013;(6):CD004878. 
62. Zhang L, Mendoza-Sassi RA, Wainwright C, Klassen TP. Nebulised hypertonic saline solution for acute bronchiolitis in infants. Cochrane Database Syst Rev 2013;(7):CD006458.

63. Teunissen J, Hochs AH, Vaessen-Verberne A, Boehmer AL, Smeets CC, Brackel H, et al. The effect of 3\% and 6\% hypertonic saline in viral bronchiolitis: a randomised controlled trial. Eur Respir J 2014;44:913-21.

64. Everard ML, Hind D, Ugonna K, Freeman J, Bradburn M, Cooper CL, et al.; SABRE Study Team. SABRE: a multicentre randomised control trial of nebulised hypertonic saline in infants hospitalised with acute bronchiolitis. Thorax 2014;69:1105-12.

65. Farley R, Spurling GK, Eriksson L, Del Mar CB. Antibiotics for bronchiolitis in children under two years of age. Cochrane Database Syst Rev 2014;(10):CD005189.

66. McCallum GB, Morris PS, Chatfield MD, Maclennan C, White AV, Sloots TP, et al. A single dose of azithromycin does not improve clinical outcomes of children hospitalised with bronchiolitis: a randomised, placebo-controlled trial. PLoS One 2013;8:e74316.

67. Tahan F, Ozcan A, Koc N. Clarithromycin in the treatment of RSV bronchiolitis: a double-blind, randomised, placebo-controlled trial. Eur Respir J 2007;29:91-7.

68. Boogaard R, Hulsmann AR, van Veen L, Vaessen-Verberne AA, Yap YN, Sprij AJ, et al. Recombinant human deoxyribonuclease in infants with respiratory syncytial virus bronchiolitis. Chest 2007;131:788-95.

69. Nenna R, Tromba V, Berardi R, De Angelis D, Papoff P, Sabbatino $\mathrm{G}$, et al. Recombinant human deoxyribonuclease treatment in hospital management of infants with moderatesevere bronchiolitis. Eur J Inflamm 2009;7:169-74.

70. Liu F, Ouyang J, Sharma AN, Liu S, Yang B, Xiong W, et al. Leukotriene inhibitors for bronchiolitis in infants and young children. Cochrane Database Syst Rev 2015;(3):CD010636.

71. Alansari K, Sayyed R, Davidson BL, Al Jawala S, Ghad- ier M. IV magnesium sulfate for bronchiolitis: a randomized trial. Chest 2017;152:113-9.

72. Kaiser SV, Bakel LA, Okumura MJ, Auerbach AD, Rosenthal J, Cabana MD. Risk factors for prolonged length of stay or complications during pediatric respiratory hospitalizations. Hosp Pediatr 2015;5:461-73.

73. Norwood A, Mansbach JM, Clark S, Waseem M, Camargo CA Jr. Prospective multicenter study of bronchiolitis: predictors of an unscheduled visit after discharge from the emergency department. Acad Emerg Med 2010;17:376-82.

74. Mansbach JM, Clark S, Piedra PA, Macias CG, Schroeder AR, Pate BM, et al.; MARC-30 Investigators. Hospital course and discharge criteria for children hospitalized with bronchiolitis. J Hosp Med 2015;10:205-11.

75. Cunningham S, Rodriguez A, Adams T, Boyd KA, Butcher I, Enderby B, et al.; Bronchiolitis of Infancy Discharge Study (BIDS) group. Oxygen saturation targets in infants with bronchiolitis (BIDS): a double-blind, randomised, equivalence trial. Lancet 2015;386:1041-8.

76. McCulloh R, Koster M, Ralston S, Johnson M, Hill V, Koehn K, et al. Use of intermittent vs continuous pulse oximetry for nonhypoxemic infants and young children hospitalized for bronchiolitis: a randomized clinical trial. JAMA Pediatr 2015;169:898-904.

77. Mazur NI, Martinón-Torres F, Baraldi E, Fauroux B, Greenough A, Heikkinen T, et al.; Respiratory Syncytial Virus Network (ReSViNET). Lower respiratory tract infection caused by respiratory syncytial virus: current management and new therapeutics. Lancet Respir Med 2015;3:888-900.

78. Mazur NI, Higgins D, Nunes MC, Melero JA, Langedijk AC, Horsley N, et al.; Respiratory Syncytial Virus Network (ReSViNET) Foundation. The respiratory syncytial virus vaccine landscape: lessons from the graveyard and promising candidates. Lancet Infect Dis 2018;18:e295-311.

79. Hubble D, Osborn GR. Acute Bronchiolitis in children. BMJ 1941;1:107-126.1, 1 .

Conflicts of interest.-The authors certify that there is no conflict of interest with any financial organization regarding the material discussed in the manuscript.

Article first published online: October 18, 2018. - Manuscript accepted: October 10, 2018. - Manuscript received: May 30, 2018. 